\title{
Characterization of resistance response of Coffea canephora genotypes to Meloidogyne incognita (Est I2) root-knot nematode
}

\author{
Anderson Vieira Santos ${ }^{1}$, Rodrigo Barros Rocha ${ }^{2}$, Silvaldo Felipe da Silveira ${ }^{3}$, \\ Alexsandro Lara Teixeira ${ }^{4}$, Sara Inácia de Matos ${ }^{5}$, José Roberto Vieira Júnior ${ }^{6}$
}

(Received: June 23, 2017; accepted: August 30, 2017)

\begin{abstract}
Meloidogynose is prominent among the factors that limit yield in C. canephora in the western Amazon, Brazil. It is caused by species of "root-knot nematode"; the most important and aggressive of these species for coffee is M. incognita. The aim of this study was to assist the selection of resistant genotypes by characterizing the reaction of 32 C. canephora clones to M. incognita (Est I2). These genotypes are selected plants from the Germplasm Bank of Embrapa Rondônia of the botanical varieties Conilon, Robusta and intervarietal hybrids. The experiments were conducted under greenhouse conditions by inoculating six seedlings for each clone with $10 \mathrm{ml}$ of suspension containing 5000 eggs of a pure inoculum of $M$. incognita. At 150 days after inoculation, evaluations were made of fresh weight of roots (FWR), total number of galls (NG), total number of eggs (NE), and the nematode reproduction factor ( $\mathrm{RF}=$ final population/initial population). In contrast with the susceptible controls of arabica coffee $(\mathrm{RF}=1.2)$ and tomato plants $(\mathrm{RF}=31.3)$, six clones of the Conilon botanical variety, five clones of the Robusta botanical variety and eight intervarietal hybrids reacted as resistant to $M$. incognita, exhibiting $\mathrm{RF}<1$ and a reduced number of galls $\left(\mathrm{NG}_{\operatorname{mean}}=<10\right)$. The clones identified as resistant in this study were integrated in the coffee breeding program in Rondônia for development of cultivars resistant to the root-knot nematode adapted to tropical conditions.
\end{abstract}

Index terms: Coffee, meloidogynose, plant selection, plant breeding, Rondônia.

\section{Caracterização da resposta de resistência de genótipos de Coffea canephora ao Nematoide-das-Galhas Meloidogyne incognita (Est I2)}

RESUMO: Entre os fatores que limitam a produtividade do C. canephora na Amazônia Ocidental destaca-se a meloidogynose, causada por espécies do "Nematoide-das-Galhas", dentre as quais a mais importante e agressiva ao cafeeiro é M. incognita. O objetivo desse trabalho foi caracterizar a resistência à $M$. incognita (Est I2) de 32 genótipos das variedades botânicas Conilon, Robusta e híbridos intervarietais provenientes do Banco de Germoplasma da Embrapa Rondônia. Os experimentos foram realizados em casa de vegetação com a inoculação de seis mudas para cada clone com $10 \mathrm{ml}$ de suspensão contendo 5000 ovos de inóculo puro de $M$. incognita. Cento e cinquenta dias após a inoculação foram avaliados o peso fresco (PF), o número de galhas $(\mathrm{NG})$, o número de ovos $(\mathrm{NO})$ e o fator de reprodução do nematoide ( $\mathrm{FR}=$ população final/população inicial). Em comparação com as testemunhas suscetíveis de café arábica e do tomateiro ( $\mathrm{FR}=1,2$ e 31,3, respectivamente), os clones da variedade botânica Conilon $(694,160,837,46,909,890)$, da variedade botânica Robusta $(1111,8152,8192,10141,8152)$ e os materiais híbridos $(844,1005,169,54,453,120,193,636)$ reagiram como resistentes à M. incognita, apresentando $\mathrm{FR}<1$ e reduzido número de galhas $\left(\mathrm{NG}_{\text {médio }}=<10\right)$. Os clones identificados como resistentes foram integrados ao programa de melhoramento genético do cafeeiro visando o desenvolvimento de cultivares resistentes ao nematoide-das-galhas e mais adaptados às condições edafoclimáticas regionais.

Termos para indexação: Café, meloidogynose, seleção de plantas, melhoramento genético, Rondônia.

\section{INTRODUCTION}

Brazil is the main worldwide exporter of coffee (Coffea spp.), with a 33.48\% share of total exports in 2015, followed by Vietnam with $18.23 \%$. In the 2016 crop season, Brazil had production of 51.37 million bags of hulled coffee, which represents growth of $18.8 \%$ compared to the previous year (ABIC, 2017). Two commercially profitable species of the Coffea coffee genus are grown in Brazil, Coffea arabica L. and Coffea canephora Pierre ex Froehner (DAVIS et al., 2011).

Phenotypic, isoenzymatic, and molecular analyses distinguish two botanical varieties in $C$. canephora species, named Conilon and Robusta Conilon (ROCHA et al, 2013). The Conilon coffee is characterized as having plants with bushy growth, early flowering, branched stems, elongated leaves, drought resistance, and greater susceptibility to diseases (RAMALHO et al., 2016, RODRIGUES et al., 2012). The Robusta coffee has greater

\footnotetext{
${ }^{1}$ Centro Universitário Luterano de Ji-Paraná - CEULJI/ULBRA - Av. Engenheiro Manfredo Barata Almeida da Fonseca, 762 Cx. P. 61 - 76.907-438 - Ji-Paraná/RO - andersonvieirasantos@msn.com

2, 4, 5, ${ }^{6}$ Embrapa Rondônia - BR 364 Km 5,5 - Zona Rural - 76.815-800 - Porto Velho-RO - rodrigo.rocha@embrapa.br, alexsandro.teixeira@embrapa.br, jose-roberto.vieira@embrapa.br, sara imatos@hotmail.com

${ }^{3}$ Universidade Estadual do Norte Fluminense Darcy Ribeiro/UENF - Av. Alberto Lamego, 2000 - Parque Califórnia - 28.013-602 Campos dos Goytacazes/RJ - silvaldo@uenf.br
} 
vegetative vigor, upright growth, larger leaves and fruit, later maturation, less tolerance to water deficit, and greater tolerance to pests and diseases, especially to coffee rust (Hemileia vastatrix) and to the root-knot nematode (Meloidogyne incognita). In the Robusta botanic variety there is the cultivar 'Apoatã', which due to its resistance to Meloidogyne spp. have served as an alternative in management of areas infested by the root-knot nematode (PAIVA et al., 2012).

Among the factors that can limit coffee yield, pests and diseases is one of the most important. Some species of plant-parasitic nematodes cause serious damage in plantations, destroying up to $80 \%$ of the root system within five years of planting (BARROS et al., 2014; SILVA et al., 2013). Plant-parasitic nematodes have a substantial economic impact on coffee in most coffee-producing countries. Among these nematodes, those of the genus Meloidogyne spp. (GÖLDI, 1887), commonly known as "root-knot nematodes", lead to economic losses in the crop. In coffee fields, the damage caused by Meloidogyne spp. vary according to the species, the population density and the susceptibility of the host cultivar (SALGADO et al., 2014; SILVA et al., 2007).

According to Amorim et al. (2011), Meloidogyne spp. cause damage to the root system, which is manifested externally by gall symptoms, splitting, and scaling in cortical tissues, causing high disorganization of root tissues. Root deformations, known as root galls or knots, are the result of excessive multiplication and growth of cells affected by the "secretions" produced by the dorsal esophageal glands of the nematodes. Other symptoms are arrested growth of the root tip, cracks, and detachment of the cortex. In the shoots, there are symptoms of chlorosis, leaf drop, and slow decline. This is reflected in the field as plant wilting during the hottest hours of the day, premature leaf drop, lower production, and symptoms of mineral deficiencies (VIEIRA JÚNIOR et al., 2015, CASTRO et al., 2008).

Five species of root-knot nematode have been reported in Brazilian coffee fields: $M$. coffeicola Lordello and Zamith, M. exigua Goeldi, M. hapla Chitwood, M. incognita (Kofoid \& White) Chitwood, and M. paranaensis Carneiro (SALGADO et al., 2015; SILVA et al., 2009). $M$. incognita is considered the most important species attacking coffee fields in Brazil, not only through its aggressiveness to coffee, but also through its wide range of hosts, which makes it difficult to control and makes it the most significant enemy of the crop (BRASS, 2008).
With the objective of selecting resistant genotypes to the root-knot nematode $M$. incognita, genotypes with greater productive potential of the Conilon and Robusta botanical varieties and of interspecific hybrids were characterized in regard to reaction to the root-knot nematode $M$. incognita (Est I2).

\section{MATERIALS AND METHODS}

\section{Genetic Resources}

Thirty-two genotypes were selected in the Germplasm Bank of Embrapa Rondônia based on the evaluation of the following morphological and productive traits: plant height (PHt), number of productive plagiotropic branches (NPLAG), distance between rosettes of the plagiotropic branch (DROS), number of coffee beans per rosette of the intermediate part of the plagiotropic branch (BROS), number of rosettes per plagiotropic branch (NROS), length of plagiotropic branch (LPLAG), length and width of leaves (LL, WL), number of days for fruit ripening (NDAYS), and coffee bean size (SIEVE). The genotypic value of production (GVProd) was estimated based on production of hulled coffee using the BLUP (Best Linear Unbiased Prediction) method (RESENDE, 2016) (Table 1).

The climate of the municipality of Ouro Preto do Oeste - RO is Aw type (Köppen classification), defined as humid tropical with a rainy season (October to May) in the summer and well-defined dry season in the winter (accumulated water deficit from June to September $(\mathrm{DEF}=175 \mathrm{~mm})$ and accumulated water excess from November to April $(\mathrm{EXC}=781 \mathrm{~mm})$ for $100 \mathrm{~mm}$ of water retention. Mean annual temperature amplitude ranges from $21.2^{\circ} \mathrm{C}$ to $30.3^{\circ} \mathrm{C}$, and the highest temperatures occur in July and August. Mean annual rainfall is $1,939 \mathrm{~mm}$ and mean relative humidity is $81 \%$ according to the Climatological Normals (BRASIL, 1992).

\section{Evaluation of resistance of $C$. canephora genotypes to $M$. incognita}

The $M$. incognita inoculation agent was extracted from $15 \mathrm{~g}$ samples of roots taken from under the canopy of diseased coffee plants that had been naturally infested in crop fields in the municipality of Ji-Paraná, RO $\left(10^{\circ} 52^{\prime} 53^{\prime}\right.$ 'S, $61^{\circ} 30^{\prime} 45^{\prime \prime} \mathrm{W}$, altitude $159 \mathrm{~m}$ ). 
TABLE 1 - Identification of genotypes (clones) of C. canephora according to the botanical varieties of the genotypic value of coffee production (GVProd), mean sieve and maturation cycle evaluated in the crop years 2013-2014 and 2014-2015 in the experimental field of Embrapa Rondônia in the municipality of Ouro Preto do Oeste, RO, Brazil.

\begin{tabular}{|c|c|c|c|c|}
\hline Genotypes & $\begin{array}{c}\text { Botanical } \\
\text { varietys }\end{array}$ & $\begin{array}{c}\text { GVProd } \\
\left(\text { bags.ha- }^{-1}\right)\end{array}$ & $\begin{array}{c}\text { Mean sieve } \\
\text { (inches }^{2} .64^{-1} \text { ) }\end{array}$ & Classification $^{\#}$ \\
\hline 890 & $\mathrm{C}$ & 101.6 & 13.4 & EMC \\
\hline 453 & $\mathrm{H}$ & 90.5 & 13.4 & EMC \\
\hline 968 & $\mathrm{C}$ & 90.0 & 14.6 & EMC \\
\hline 193 & $\mathrm{H}$ & 87.3 & 14.9 & EMC \\
\hline 160 & $\mathrm{C}$ & 85.7 & 15.5 & EMC \\
\hline 1111 & $\mathrm{R}$ & 85.0 & 16.1 & IMC \\
\hline 837 & $\mathrm{C}$ & 85.0 & 12.9 & EMC \\
\hline 694 & $\mathrm{C}$ & 84.7 & 14.5 & EMC \\
\hline 8152 & $\mathrm{R}$ & 82.0 & 15.8 & LMC \\
\hline 8152 & $\mathrm{R}$ & 82.0 & 15.8 & IMC \\
\hline 657 & $\mathrm{H}$ & 80.3 & 13.9 & IMC \\
\hline 772 & $\mathrm{C}$ & 80.0 & 14.0 & EMC \\
\hline 8192 & $\mathrm{R}$ & 78.0 & 14.4 & LMC \\
\hline 10141 & $\mathrm{R}$ & 76.0 & 16.5 & IMC \\
\hline 703 & $\mathrm{C}$ & 75.0 & 15.9 & EMC \\
\hline 535 & $\mathrm{H}$ & 73.1 & 15.5 & IMC \\
\hline 56 & $\mathrm{H}$ & 68.2 & 16.7 & IMC \\
\hline 46 & $\mathrm{C}$ & 68.0 & 15.8 & EMC \\
\hline 909 & $\mathrm{C}$ & 66.7 & 14.8 & EMC \\
\hline 54 & $\mathrm{H}$ & 66.0 & 14.1 & EMC \\
\hline 482 & $\mathrm{H}$ & 59.9 & 16.6 & IMC \\
\hline 796 & $\mathrm{C}$ & 59.2 & 15.3 & EMC \\
\hline 844 & $\mathrm{H}$ & 57.0 & 14.8 & EMC \\
\hline 120 & $\mathrm{H}$ & 56.4 & 15.0 & EMC \\
\hline 169 & $\mathrm{H}$ & 56.0 & 15.5 & EMC \\
\hline 792 & $\mathrm{C}$ & 55.6 & 14.6 & EMC \\
\hline 799 & $\mathrm{C}$ & 53.3 & 16.0 & IMC \\
\hline 723 & $\mathrm{C}$ & 52.8 & 13.5 & EMC \\
\hline 750 & $\mathrm{H}$ & 51.6 & 15.1 & EMC \\
\hline 636 & $\mathrm{H}$ & 51.0 & 14.9 & EMC \\
\hline 1005 & $\mathrm{H}$ & 50.0 & 14.8 & EMC \\
\hline 729 & $\mathrm{C}$ & 49.3 & 12.9 & EMC \\
\hline
\end{tabular}

${ }^{\Phi} \mathrm{C}$ : Conilon botanical variety, R: Robusta botanical variety, H: Conilon x Robusta hybrid genotype. ${ }^{*}$ EMC: early maturation cycle, IMC: intermediate maturation cycle, LMC: late maturation cycle. 
In laboratory conditions, the egg mass of a single female nematode at an advanced stage of oviposition was extracted under a stereoscopic microscope and transferred to an Eppendorf tube containing $0.1 \mathrm{ml}$ of $1 \%$ saline solution. Immediately after the suspension with the egg mass was transferred to a test tube containing 10 $\mathrm{mL}$ of sterilized distilled water, which was placed in a vortex shaker for approximately 15 seconds, until the eggs were separated from the ootheca and the suspension was homogeneous. An automatic pippetor was used to individually inoculate 3.3 $\mathrm{mL}$ of the suspension containing nematode eggs on three cv. Santa Clara tomato plants (Solanum lycopersicum L.) with an age of 20 days after germination kept in 8 liter pots with sterilized substrate.

To facilitate nematode infection on the roots, a perforation of approximately $3 \mathrm{~cm}$ into the substrate was made near the base of each plant using a glass rod; at this point, the suspension was pipetted. In the first week after inoculation, the plants were irrigated with $50 \mathrm{~mL}$ of sterilized distilled water so that the nematode eggs would not be leached by the irrigation. After that, the tomato plants were irrigated for 80 days in a greenhouse until the nematodes multiplied sufficiently to set up the resistance trials.

In order to identify the species of the rootknot nematode, enzymatic characterization of the esterase profile was performed in the Embrapa Temperate Climate Plant Pathology Laboratory RS through electrophoresis of isoenzymes coming from one of the infected tomato plants, according to the methodology of Carneiro \& Almeida (2001). Females of Meloidogyne javanica (Treub) Chitwood, 1949 were used as control samples. The esterase profile observed was of a single typical pattern of M. incognita (Est I2).

The trial for evaluation of resistance of the coffee genotypes to root-knot nematode was carried out from July to December 2015 in Ji-Paraná, RO, in the experimental field of the Centro Universitário Luterano de Ji-Paraná - CEULJI/ULBRA $\left(10^{\circ} 52^{\prime} 53^{\prime \prime} \mathrm{S}\right.$ and $61^{\circ} 30^{\prime} 45^{\prime \prime} \mathrm{W}$ and altitude of 159 meters).

Seedlings of 32 genotypes of C. canephora (Table 1) at six months of age were transplanted to 8-liter pots containing sterilized substrate composed of sand, vermiculite, natural soil, and organic compost $(1: 1: 1: 1)$ and arranged on benches in a gable roof greenhouse. Each one of the 32 genotypes of C. canephora (Table 1) were inoculated with $M$. incognita represented a treatment using six replications for each clone, which were arranged in a completely randomized design and kept in a greenhouse. Clones of $C$. canephora of the Apoatã cultivar, identified by the numbers "1322", "1326", and "1327", were evaluated as resistant controls. The C. arabica IAC Obatã 1669-20 cultivar was used as a susceptible control, as already described for the other inoculated seedlings. Tomato plants cv. Santa Clara at 20 days after germination were also used for this purpose and were grown in 8-L pots with the same substrate cited for the coffee seedlings; they were inoculated at the same time to evaluate the quality of the inoculum and to ensure maintenance of the inoculum for other studies in process.

For inoculation of the C. canephora genotypes two weeks after transplanting the seedlings, nematode eggs multiplied on tomato roots were extracted according to Hussey \& Barker (1973). Each coffee plant was inoculated separately by irrigation of the substrate in the pot with $10 \mathrm{ml}$ of suspension containing 5,000 eggs + second stage juveniles (J2) of M. incognita (Est I2). Tomato plants were evaluated regarding reaction to M. incognita (Est I2) at 90 days after inoculation (DAI). The evaluation of coffee plants was at 150 DAI. For this evaluation, the roots of each plant were separated from the shoots, washed, and weighed, and the number of galls were counted. After that, the roots were processed according to the methodology of Hussey \& Barker (1973) to determine the number of eggs and the reproduction factor $(\mathrm{RF})$ of $M$. incognita $(\mathrm{RF}=$ final population / initial population) in the different genotypes evaluated. To calculate RF, the final population is considered as the total number of nematode eggs extracted from each coffee plant; the number of eggs were counted on a Peter's slide under an optical microscope. The initial population is that which was inoculated $(5000$ eggs $+\mathrm{J} 2)$. The treatments that had $\mathrm{RF}<1.00$ were considered resistant, those with $R F=0.00$ as immune, and those with RF $>1.00$ as susceptible (OOSTENBRINK, 1966). The RF values were used to classify reaction of the coffee plants to M. incognita by the criteria of Seinhorst (1967), in which plants with $\mathrm{RF}<1$ are considered poor hosts (PH), with $\mathrm{RF} \geq 1$ are considered good hosts $(\mathrm{GH})$, and $\mathrm{RF}=0$ are considered non-hosts $(\mathrm{NH})$. Susceptibility of the plants was also classified, considering resistant plants as those with scores 
1,2 , and 3 and susceptible plants as those with scores 4,5 , and 6 , based on criteria modified from SASSER et al. (1984), who classified plants as resistant $(\mathrm{R})$ that had a root system with number of galls less than or equal to 10 , whereas those with higher values were considered susceptible (S).

\section{Statistical methods}

To quantify the reaction of the genotypes (clones) of C. canephora to $M$. incognita (Est I2), the data collected from each variable were interpreted considering the following model:

$$
\mathrm{Y}_{\mathrm{ij}}=\mathrm{u}+\mathrm{G}_{\mathrm{i}}+\mathrm{e}_{\mathrm{ij}}
$$

in which $Y_{\mathbf{i}}=$ observation of the $\mathrm{i}$-th clone in the $j$-th replication, $u=$ overall mean, $G_{i}=$ effect of the $i$-th clone, and $e_{i}=$ random error associated with the $\mathrm{i}$-th clone and in the $\mathrm{j}$-th replication. The Scott-Knott test at $5 \%$ probability was used to test the equality hypothesis between the means of groups.

The estimates of genotypic, environmental, and phenotypic variance were obtained to quantify the proportion of total variance due to the effects of genotypes and environments (CRUZ, 2016). The genetic parameters, broad sense heritability, genotypic and environmental coefficients of variation, and intraclass correlation were estimated from the variance components. The significant estimates of the Pearson correlation coefficient were used to interpret the association between the reproduction factor (RF) and morphological and productive traits. The statistical analyses were performed using the GENES software (CRUZ, 2016).

\section{RESULTS AND DISCUSSION}

According to the $\mathrm{F}$ test of analysis of variance, the effects of clones, controls, and the contrast of clones vs. control were significant at $1 \%$ probability for fresh weight of roots (FWR), number of galls (NG), number of eggs (NE), and reproduction factor (RF) of the $M$. incognita nematode (Table 2).

As expected, the tomato cv. Santa Clara is a very susceptible host to $M$. incognita, exhibiting $\mathrm{RF}=31.3$ and $\mathrm{NG}=731$ at 90 DAI. As most Coffea arabica cultivars are hosts susceptible to Meloidogyne spp. (KANAYAMA et al., 2009), the $C$. arabica cultivar Obatã was considered a good host (GH) of $M$. incognita at 150 DAI, with $\mathrm{RF}=1.2$ by the classification of Seinhorst
(1967) and susceptible (S) by the classification of Sasser (1984), exhibiting a high number of galls $(\mathrm{NG}=11)$. These results furthermore attest to the quality of the inoculum of $M$. incognita (Est I2) used in the coffee plant genotype inoculation trial. In contrast, the three $C$. canephora resistant controls of the Apoatã cultivar were classified as non-hosts $(\mathrm{NH})$ for $M$. incognita $(\mathrm{RF}=0)$, according to the classification of Seinhorst (1967), or as resistant $(\mathrm{NG}=0.0,0.0$, and 0.87$)$, according to Sasser (1984), in the evaluations made at 150 DAI. At that time, few gall symptoms among the plants known as resistant were observed, only on clone $1326(\mathrm{NG}=0.87)$ (Table 4). Such results confirm the resistance of the cultivar Apoatã which has been used as an alternative in control of root-knot nematodes. The clone Apoatã "IAC 2258 " is recommended as rootstock resistant to Meloidogyne spp. in São Paulo for planting grafted seedlings in areas infested with the nematodes $M$. exigua and M. incognita (Kofoid \& White) Chitwood and $M$. paranaensis (RAMALHO et al., 2009). In São Paulo, the mean yield of the ungrafted susceptible genotypes was an average of $55 \%$ lower than the yield of the same genotypes grafted on the cv. IAC Apoatã 2258 (BARBOSA et al., 2014).

The characteristics that have the higher coefficients of variation were $\mathrm{RF}>\mathrm{NG}>\mathrm{NE}>\mathrm{FWR}$ (Table 3). Santos et al. (2017) evaluated the reaction of the C. canephora cultivar 'BRS Ouro Preto' to M. incognita (Est I2) and observed an experimental coefficient of variation of $26,94 \%$ to the reproduction factor (RF). Santos and Gomes (2011), evaluating the reaction of castor bean cultivars to six species of Meloidogyne, observed an experimental coefficient of variation of $36.6 \%$ and $47.7 \%$ for RF and NG respectively. Although the resistance trials are conducted in a controlled environment, they are biological experiments that are influenced by environment factors. The experimental coefficient of variation of 36.06 for NG and 36.74 for FR are comparable to the estimates obtained in other studies (CONTARATO et al., 2014).

The heritability measures the relative proportion between the genotypic and environmental effects in expression of the resistance (CRUZ, 2016). The heritability estimates of 94,94 for FWR, 96,12 for NG, 97,99 for NE, and 96,78 for RF may be considered high and indicates predominance of the genotypic component in expression of root knot resistance (Table 3). The larger influence of the genotype effect on the expression indicates the genetic progress through plant selection. 
TABLE 2 - Results of analyses of variance of the characteristics of fresh weight of roots (FWR), number of galls (NG), number of eggs (NE), and reproduction factor (RF) of the nematode $M$. incognita (Est I2) in 32 genotypes of Coffea canephora evaluated at 150 days after inoculation.

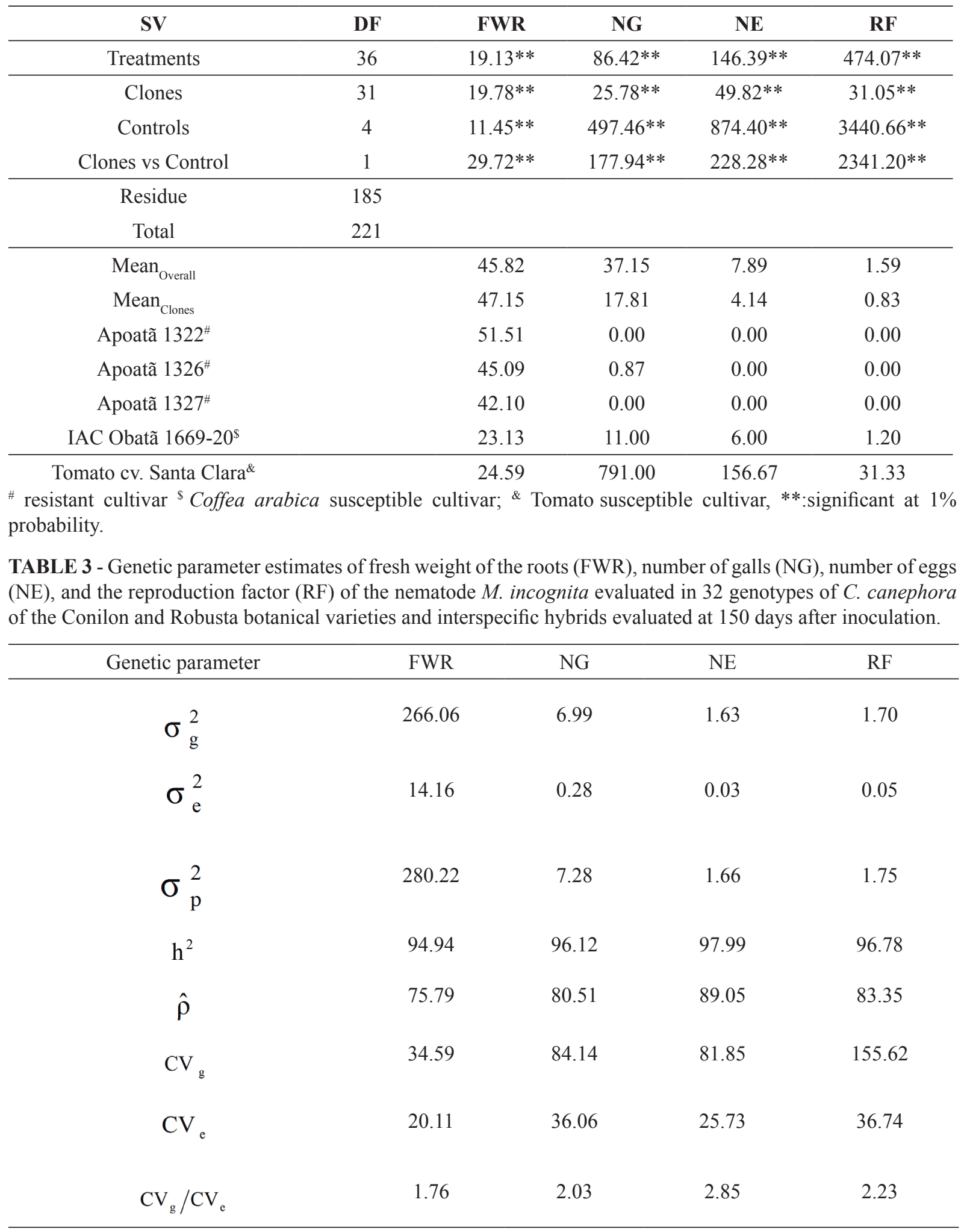


Estimates of the coefficient of genetic variation $(\mathrm{CVg})$ above the coefficient of environmental variation $(\mathrm{CVe})$ characterize a favorable condition to obtain gains with the selection of resistant plants. The $\mathrm{CVg} / \mathrm{CVe}$ ratio showed an amplitude of 1.76 for FWR and 2.85 for NE indicating that the first trait had higher environmental influence than the first one.

Although C. canephora is considered a species more resistant to root-knot nematode, the clones of $C$. canephora 750, 703, 772, 729, 799, 792, 796, 968, and 723 were considered good hosts of $M$. incognita, with levels of susceptibility greater than the $C$. arabica cultivar Obatã susceptible control (Table 4). Therefore, the clones cited above can be used as susceptible comparisons in new trials of reaction of the coffee plant to M. incognita (Est I2) in Rondônia. Among these materials, the clone hybrid 750 stood out through its high susceptibility to $M$. incognita, with $\mathrm{RF}=5.68$.

In contrast, of the 32 genotypes of $C$. canephora evaluated in this experiment, 23 (71\%) were poor hosts $(\mathrm{PH})$ of $M$. incognita because at $150 \mathrm{DAI}$, they had a reproduction factor less than $1(\mathrm{RF}<1)$ (Table 4). All five clones of the Robusta botanical variety were classified as poor hosts of $M$. incognita $(\mathrm{RF}<1)$ at 150 DAI, with a mean reproduction factor of 0.25 . These data corroborate other studies involving the resistance of C. canephora to Meloidogyne spp., especially within accessions of Robusta coffee (BARBOSA et al., 2014).

The intervarietal hybrids, with the exception of clone 750 which was classified as a good host $(\mathrm{RF}=5.68)$, all the others $(844,1005, \mathrm{H} 56,169$, $657, \mathrm{H} 54,453,120,193,535,482$, and 636) were classified as poor hosts $(\mathrm{PH})$, with $\mathrm{RF}<1$ (Table 4). Six genotypes of the Conilon botanical variety $(890,837,046,909,694$, and 160) were poor hosts $(\mathrm{PH})$ of $M$. incognita $(\mathrm{RF}<1)$ and eight clones of the Conilon botanical variety $(703,772,729,799$, 792, 796, 968, and 723) were considered good hosts $(\mathrm{GH})$ of $M$. incognita at $150 \mathrm{DAI}\left(\mathrm{RF}_{\text {mean }}=\right.$ 1.24) (Table 5).

According to the number of gals (NG), the genotypes characterized as poor hosts $(\mathrm{PH})$ were also classified as resistant $(\mathrm{R})(\mathrm{NG}<10)$, except for the clones $1005(\mathrm{NG}=12.16)$ and $657(\mathrm{NG}=13.5)$, that were classified as susceptible (SASSER, 1984). Concerning the genotypes classified as good hosts $(\mathrm{GH})$ to the nematode (RF>1), only clone 797 of Conilon coffee was considered resistant $(\mathrm{NG}=8.6)$ (Table 4). According to Amorim et al. (2011), the presence of galls is one of the symptomatological aspects of the disease, and plant resistance refers to its capacity to supress multiplication of the pathogen. Evaluation of the presence and of the number of galls alone should not be considered in evaluation of resistance because resistant plants can form galls in the presence of few nematodes and susceptible plants might not produce galls. Santos et al., 2017, evaluating the resistance of $C$. canephora to $M$. incognita (Est I2), found that part of the clones considered resistant $(\mathrm{RF}<1)$ responded as susceptible when considering only the number of galls. This suggests that although the nematode induces formation of galls in Coffea spp., few were reproduced in the clones evaluated.

Of the nine clones classified as good hosts (GH) of $M$. incognita at 150 DAI, except for genotypes 750 and 796, which had reduced fresh weight of roots (FWR), the seven remaining clones of Conilon coffee 703, 772, 729, 799, 792, 968, and 723 had FWR results similar or superior to the resistant controls of cv. Apoatã (var. Robusta) (Table 4). Although these genotypes allowed multiplication of the nematode $(\mathrm{RF}>1)$, there was not significant damage in their roots compared to the Apoatã controls (resistant), which have a voluminous root system (PAIVA et al., 2012). However, tolerance to damage may be separate from resistance because it refers to the ability of a given host plant to compensate or recover from adverse effects of attack from a determined nematode and, nevertheless, produce well (VANSTONE et al., 2008).

Of the 23 clones considered poor hosts $(\mathrm{PH})$ of $M$. incognita, only seven (844, 1005, H54, 837, 909, 193, and 694) exhibited FWR lower than the plants of the resistant control Apoatã (Table 4). DAMATTA et al. (2007) report that selecting clones with a more voluminous root system may be successful to develop resistant cultivars, because this is a trait favorable to rootstock cultivars. Resistance of the C. canephora Apoatã cultivar is associated with its vigorous root system (BARBOSA, et al., 2014, VILLAIN et al., 2010). The hypersensitivity reaction and impediment to the formation of giant cells is the resistance mechanism most accepted for explaining the incompatibility of the coffee plant to the root-knot nematode (LIMA et al., 2015; SILVA et al., 2013).

The Conilon and Robusta botanical varieties and their interspecific hybrids exhibited significant differences in estimates of RF. The Robusta botanical variety exhibited higher resistance $\left(\mathrm{RF}_{\text {(Robusta) }}=1.24\right)$ than the intervarietal hybrids $\left(\mathrm{RF}_{\text {(Hybrids) }}=0.63\right)$ and the Conilon botanical variety $\left(\mathrm{RF}_{\text {(Conilon) }}=0.16\right)($ Table 5$)$. 
TABLE 4 - Means of fresh weight of roots (FWR), number of galls (NG), number of eggs (NE), and reproduction factor (RF) of the root-knot nematode $M$. incognita (Est I2) in coffee plant genotypes (C. canephora) obtained at 150 days after inoculation with 5000 nematode eggs.

\begin{tabular}{|c|c|c|c|c|c|c|c|}
\hline Genotype & $\begin{array}{c}\text { Botanical } \\
\text { Variety }\end{array}$ & FWR & NG & $\mathrm{C}$ & $\mathrm{NE}^{1}$ & $\mathrm{RF}$ & $\mathrm{C}$ \\
\hline 750 & $\mathrm{H}$ & $25.71 d$ & $130.06 \mathrm{a}$ & $\mathrm{S}$ & $28.40 \mathrm{a}$ & $5.68 \mathrm{a}$ & $\mathrm{GH}$ \\
\hline 703 & $\mathrm{C}$ & $69.86 a$ & $79.00 \mathrm{~b}$ & $\mathrm{~S}$ & $22.71 b$ & $4.53 b$ & $\mathrm{GH}$ \\
\hline 772 & $\mathrm{C}$ & $43.48 \mathrm{c}$ & $63.33 b$ & $\mathrm{~S}$ & $14.46 \mathrm{c}$ & $2.90 \mathrm{c}$ & $\mathrm{GH}$ \\
\hline 729 & $\mathrm{C}$ & $68.35 \mathrm{a}$ & $73.3 b$ & $\mathrm{~S}$ & $11.4 \mathrm{c}$ & $2.28 \mathrm{c}$ & $\mathrm{GH}$ \\
\hline 799 & $\mathrm{C}$ & $55.25 b$ & $13.17 \mathrm{c}$ & $\mathrm{S}$ & $7.87 \mathrm{~d}$ & $1.58 \mathrm{~d}$ & $\mathrm{GH}$ \\
\hline 792 & $\mathrm{C}$ & $69.7 \mathrm{a}$ & $63.83 b$ & $\mathrm{~S}$ & $7.53 \mathrm{~d}$ & $1.53 \mathrm{~d}$ & $\mathrm{GH}$ \\
\hline 796 & $\mathrm{C}$ & $31.12 \mathrm{~d}$ & $8.60 c$ & $\mathrm{R}$ & $6.13 d$ & $1.23 \mathrm{~d}$ & $\mathrm{GH}$ \\
\hline 968 & $\mathrm{C}$ & $69.16 \mathrm{a}$ & $14.60 \mathrm{c}$ & $\mathrm{S}$ & $6.11 \mathrm{~d}$ & $1.21 \mathrm{~d}$ & $\mathrm{GH}$ \\
\hline 723 & $\mathrm{C}$ & $69.48 \mathrm{a}$ & $19.33 c$ & $\mathrm{~S}$ & $5.91 \mathrm{~d}$ & $1.20 \mathrm{~d}$ & $\mathrm{GH}$ \\
\hline 844 & $\mathrm{H}$ & $32.15 d$ & $2.00 \mathrm{~d}$ & $\mathrm{R}$ & $2.33 \mathrm{e}$ & $0.47 \mathrm{e}$ & $\mathrm{PH}$ \\
\hline 1111 & $\mathrm{R}^{2}$ & $41.36 c$ & $2.33 \mathrm{~d}$ & $\mathrm{R}$ & $2.15 \mathrm{e}$ & $0.45 \mathrm{e}$ & $\mathrm{PH}$ \\
\hline 1005 & $\mathrm{H}$ & $31.43 \mathrm{~d}$ & $12.16 \mathrm{c}$ & $\mathrm{S}$ & $1.50 \mathrm{e}$ & $0.30 \mathrm{e}$ & $\mathrm{PH}$ \\
\hline 8102 & $\mathrm{R}$ & $64.75 \mathrm{a}$ & $1.50 \mathrm{~d}$ & $\mathrm{R}$ & $1.33 \mathrm{e}$ & $0.27 \mathrm{e}$ & $\mathrm{PH}$ \\
\hline H56 & $\mathrm{H}$ & $69.66 a$ & $5.00 \mathrm{c}$ & $\mathrm{R}$ & $1.28 \mathrm{e}$ & $0.26 \mathrm{e}$ & $\mathrm{PH}$ \\
\hline 169 & $\mathrm{H}$ & $59.08 b$ & $7.33 c$ & $\mathrm{R}$ & $1.26 \mathrm{e}$ & $0.25 \mathrm{e}$ & $\mathrm{PH}$ \\
\hline 657 & $\mathrm{H}$ & $40.08 \mathrm{c}$ & $13.50 \mathrm{c}$ & $\mathrm{S}$ & $1.21 \mathrm{e}$ & $0.25 \mathrm{e}$ & $\mathrm{PH}$ \\
\hline H54 & $\mathrm{H}$ & $25.53 d$ & $5.83 c$ & $\mathrm{R}$ & $1.10 \mathrm{e}$ & $0.23 \mathrm{e}$ & $\mathrm{PH}$ \\
\hline 8192 & $\mathrm{R}$ & $61.2 \mathrm{a}$ & $0.66 \mathrm{~d}$ & $\mathrm{R}$ & $1.03 \mathrm{e}$ & $0.23 \mathrm{e}$ & $\mathrm{PH}$ \\
\hline 453 & $\mathrm{H}$ & $63.82 \mathrm{a}$ & $1.83 \mathrm{~d}$ & $\mathrm{R}$ & $1.00 \mathrm{e}$ & $0.20 \mathrm{e}$ & $\mathrm{PH}$ \\
\hline 120 & $\mathrm{H}$ & $35.46 \mathrm{c}$ & $6.83 c$ & $\mathrm{R}$ & $0.95 \mathrm{e}$ & $0.20 \mathrm{e}$ & $\mathrm{PH}$ \\
\hline 890 & $\mathrm{C}$ & $51.31 \mathrm{~b}$ & $3.16 \mathrm{~d}$ & $\mathrm{R}$ & $0.86 \mathrm{e}$ & $0.18 \mathrm{e}$ & $\mathrm{PH}$ \\
\hline 10141 & $\mathrm{R}$ & $50.45 b$ & $1.66 \mathrm{~d}$ & $\mathrm{R}$ & $0.85 f$ & $0.18 \mathrm{e}$ & $\mathrm{PH}$ \\
\hline 837 & $\mathrm{C}$ & $26.78 d$ & $8.20 \mathrm{c}$ & $\mathrm{R}$ & $0.81 \mathrm{f}$ & $0.18 \mathrm{e}$ & $\mathrm{PH}$ \\
\hline 46 & $\mathrm{C}$ & $46.85 c$ & $2.6 \mathrm{~d}$ & $\mathrm{R}$ & $0.78 \mathrm{f}$ & $0.15 \mathrm{e}$ & $\mathrm{PH}$ \\
\hline 909 & $\mathrm{C}$ & $27.48 \mathrm{~d}$ & $4.33 \mathrm{~d}$ & $\mathrm{R}$ & $0.71 \mathrm{f}$ & $0.15 \mathrm{e}$ & $\mathrm{PH}$ \\
\hline 8152 & $\mathrm{R}$ & $66.28 \mathrm{a}$ & $2.50 \mathrm{~d}$ & $\mathrm{R}$ & $0.60 \mathrm{f}$ & $0.13 \mathrm{e}$ & $\mathrm{PH}$ \\
\hline 193 & $\mathrm{H}$ & $18.98 d$ & $5.20 \mathrm{c}$ & $\mathrm{R}$ & $0.51 \mathrm{f}$ & $0.11 \mathrm{e}$ & $\mathrm{PH}$ \\
\hline 694 & $\mathrm{C}$ & $22.36 \mathrm{~d}$ & $8.20 \mathrm{c}$ & $\mathrm{R}$ & $0.48 \mathrm{f}$ & $0.10 \mathrm{e}$ & $\mathrm{PH}$ \\
\hline 160 & $\mathrm{C}$ & $53.15 b$ & $2.80 \mathrm{~d}$ & $\mathrm{R}$ & $0.38 \mathrm{f}$ & $0.10 \mathrm{e}$ & $\mathrm{PH}$ \\
\hline 535 & $\mathrm{H}$ & $43.08 \mathrm{c}$ & $1.66 \mathrm{~d}$ & $\mathrm{R}$ & $0.36 f$ & $0.08 \mathrm{e}$ & $\mathrm{PH}$ \\
\hline 482 & $\mathrm{H}$ & $35.63 c$ & $2.33 \mathrm{~d}$ & $\mathrm{R}$ & $0.31 \mathrm{f}$ & $0.08 \mathrm{e}$ & $\mathrm{PH}$ \\
\hline 636 & $\mathrm{H}$ & $39.95 c$ & $3.16 \mathrm{~d}$ & $\mathrm{R}$ & $0.26 \mathrm{f}$ & $0.06 \mathrm{e}$ & $\mathrm{PH}$ \\
\hline Apoatã 1322 & $\mathrm{R}$ & $51.51 b$ & $0.00 \mathrm{e}$ & $\mathrm{R}$ & $0.00 \mathrm{~g}$ & $0.00 \mathrm{f}$ & $\mathrm{NH}$ \\
\hline Apoatã 1326 & $\mathrm{R}$ & $45.08 \mathrm{c}$ & $0.87 \mathrm{e}$ & $\mathrm{R}$ & $0.00 \mathrm{~g}$ & $0.00 \mathrm{f}$ & $\mathrm{NH}$ \\
\hline Apoatã 1327 & $\mathrm{R}$ & $42.10 \mathrm{c}$ & $0.00 \mathrm{e}$ & $\mathrm{R}$ & $0.00 \mathrm{~d}$ & $0.00 \mathrm{~d}$ & $\mathrm{NH}$ \\
\hline Obatã 1669-20 & - & $23.10 \mathrm{~d}$ & $11.00 \mathrm{c}$ & $\mathrm{S}$ & $6.00 \mathrm{~d}$ & $1.20 \mathrm{~d}$ & $\mathrm{GH}$ \\
\hline TomatoSta.Cruz & - & 24.60 & 791.00 & $\mathrm{~S}$ & 156.7 & 31.30 & $\mathrm{GH}$ \\
\hline
\end{tabular}

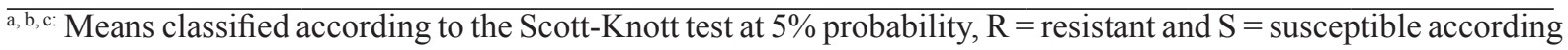
to Sasser et al. (1984); ${ }^{2} \mathrm{NH}=$ non host; $\mathrm{PH}=$ poor host, and $\mathrm{GH}=$ good host, according to Seinhorst 
TABLE 5 - Estimates of correlation between the reproduction factor (RF) of Meloidogyne incognita (Est I2) and eleven morphological and productive traits of Conilon and Robusta botanical varieties and their intervarietal hybrids, belonging to the Germplasm Bank of Embrapa Rondônia, Brazil.

\begin{tabular}{|c|c|}
\hline Variables & Correlation \\
\hline PHt x RF & $-0.25^{\mathrm{NS}}$ \\
\hline NPLAG x RF & $0.04^{\mathrm{NS}}$ \\
\hline NROS x RF & $-0.08^{\mathrm{NS}}$ \\
\hline LPLAG $\times$ RF & $-0.32 *$ \\
\hline DROS x RF & $-0.08^{\mathrm{NS}}$ \\
\hline BROS x RF & $-0.33^{*}$ \\
\hline NDAYS x RF & $-0.25^{\mathrm{NS}}$ \\
\hline GVprod $x$ RF & $-0.05^{\mathrm{NS}}$ \\
\hline $\mathrm{LL} \times \mathrm{RF}$ & $-0.24^{\mathrm{NS}}$ \\
\hline WL $x$ RF & $-0.36^{*}$ \\
\hline SIEV x RF & $-0.34 *$ \\
\hline Mean RF (Robusta) & $1.24^{\mathrm{a}}$ \\
\hline Mean RF ${ }_{\text {(Hybrids) }}$ & $0.63^{b}$ \\
\hline Mean RF (Conilon) & $0.16^{\mathrm{c}}$ \\
\hline \multicolumn{2}{|c|}{ 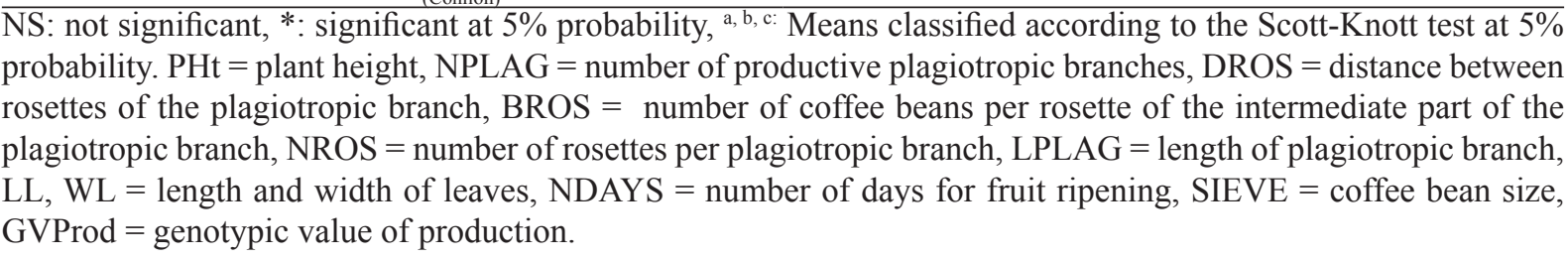 } \\
\hline
\end{tabular}

The larger leaf size, larger bean size, longer plagiotropic branches, and greater number of beans per rosette were inversely associated with the resistance factor (Table 5). These are typical traits of the Robusta botanical variety that corroborates the higher resistance of this germplasm. Important traits such as the coffee bean yield did not present significant correlation with resistance to nematodes.

In Brazil, the Robusta variety, represented by the cultivar Apoatã IAC 2258 (C. canephora cv. 2.258 from the CATIE germplasm collection, Turrialba, Costa Rica) is one of the most used as rootstock resistant to Meloidogyne for the purpose of planting in infested areas. In Central America, the "Nemaya" cultivar, derived from the cross between the clones of $C$. canephora T3561 and T3751, has allowed the survival and competitiveness of coffee growing in regions infested by Meloidogyne (ANTHONY et al., 2007). Both cultivars are derived from the clone T3561 and exhibit multiple resistance to $M$. exigua, M. incognita, and $M$. paranaenses (LIMA et al., 2015).
These $C$. canephora genotypes resistant to $M$. incognita selected in this study can constitute sources of resistance for development of Conilon coffee cultivars with superior traits adapted to the soil and climate conditions of Rondônia.

\section{CONCLUSIONS}

At $150 \mathrm{DAI}$, the $C$. canephora clones of the Conilon botanical variety $694,160,837,46$, 909 , and 890 and the hybrid materials 844,1005 , $169,54,453,120,193$, and 636, all considered as having an early cycle and fruit maturation, respond as resistant to $M$. incognita and can be used in plant breeding programs for the purpose of obtaining early cycle coffee cultivars that are resistant to this nematode in Rondônia. The five clones of $C$. canephora of the Robusta botanical variety $1111,8152,8192,10141$, and 8152 were confirmed as resistant to $M$. incognita. The clones Apoatã 1322, Apoatã 1326, and Apoatã 1327 belonging to the Robusta botanical variety were confirmed as immune (non-hosts) of $M$. incognita and can be used as rootstock, with a view toward planting in infested areas and as sources of resistance to $M$. incognita. 


\section{ACKNOWLEDGEMENTS}

The authors thank to the Conselho Nacional de Desenvolvimento Científico e Tecnológico $(\mathrm{CNPq})$ for the scholar ship grant. We also gratefully acknowledge the Consórcio Pesquisa Café for financial support.

\section{REFERENCES}

CASTRO, J. M. C. et al. Levantamento de fitonematoides em cafezais do Sul de Minas Gerais. Nematologia Brasileira, Brasília, v.32, n.1, p.56-64, jan/mar. 2008.

CONTARATO C. C. et al. Reaction of Cultivar Coffee Vitória INCAPER 8142 of Conillon to Parasitism of Meloidogyne exigua. Idesia (Arica. Impresa), Tarapacá, v. 32, n.1, p. 93-97, Jan/Feb. 2014.

CRUZ, C. D. Genes Software - extended and integrated with the R, Matlab and Selegen. Acta Scientiarum Agronomy (Online), Maringá, v. 38, n. 4, p. 547-552, Oct/Dez. 2016.

DAMATTA, F. M. et al. Ecophysiology of coffee growth and production: review. Brazilian Journal of Plant Physiology, Campinas, v. 19, n. 4, p. 485-510, Oct/Dec. 2007.

DAVIS, A. P. et al. Growing coffee: Psilanthus (Rubiaceae) subsumed on the basis of molecular and morphological data; implications for the size, morphology, distribution and evolutionary history of Coffea. Botanical Journal of the Linnean Society, Londres, v. 167, n. 4, p. 357-377, Oct. 2011.

GÖLDI, E. A. Relatório sobre a moléstia do cafeeiro na Província do Rio de Janeiro, 1887. Recife: UFRPE. Fadurpe, 121 p, 1998. (Reeditado por Roberto Marinho Moura).

HUSSEY, R. S.; BARKER, K. B. A comparison of methods of collecting inocula for Meloidogyne spp., including a new technique. Plant Disease, Iowa, v. 57, n. 12, p. 1025-1028, Dec. 1973.

KANAYAMA, F. S. et al. Progênies de Coffea arabica cv. IPR 100 com resistência ao nematoide Meloidogyne incognita raça 1. Ciência e Agrotecnologia, Lavras, v. 33, n. 1, p. 1321-1326, Jan/Feb. 2009.
LIMA, E. A. et al. The multi-resistant reaction of drought tolerant coffee 'Conilon clone 14' to Meloidogyne spp. and late hypersensitivelike response in Coffea canephora. Phytopathology, Iowa, v. 105, n. 6, p. 805-814, June. 2015.

OOSTENBRINK, M. Major characteristics of the relation between nematodes and plants. Mendelingen Landbouwhogeschool Wageningen, Wageningen, v. 6, n. 4, p. 1-46, 1966.

PAIVA, R. F. et al. Comportamento de cultivares de cafeeiros C. arabica L. enxertados sobre cultivar 'Apoatã IAC 2258' (Coffea canephora). Ciência Rural, Santa Maria, v. 42, n. 7, p. 1155-1160, jul. 2012.

RAMALHO, A. R. et al. Progresso genético da produtividade de café beneficiado com a seleção de clones de cafeeiro Conilon. Revista Ciência Agronômica, Fortaleza, v. 47, n. 3, p. 516-523, jul/set. 2016.

RAMALHO, A. R. et al. Cultivares de cafeeiros Conilon e Robusta indicadas para o Estado de Rondônia. Comunicado Técnico, v. 348, p. 1-10, abr. 2009.

RESENDE, M. D. V. Software Selegen-REML/BLUP: a useful tool for plant breeding. Crop Breeding and Applied Biotechnology, Londrina, v. 16, n. 4, p. 330339, Oct/Dec. 2016.

ROCHA, R. B. et al. Caracterização e uso da variabilidade genética de banco ativo de germoplasma de Coffea canephora Pierre ex Froehner. Coffee Science, Lavras, v. 8, n. 4, p. 478-485, out/dez. 2013.

RODRIGUES, W. N. et al. Estimativa de parâmetros genéticos de grupos de clones de café conilon. Coffee Science, Lavras, v. 7, n. 2, p. 177-186, mai/ago. 2012.

SALGADO, S. M. L.; REZENDE, J. C.; NUNES, J. A. R Selection of coffee genotypes for resistance to nematode Meloidogyne paranaensis in infested area. Crop Breeding and Applied Biotechnology, Londrina, v. 14, n. 2, p. 94-101, Apr/June. 2014.

SALGADO, S. M. L. et al. Meloidogyne paranaensis e Meloidogyne exigua em lavouras cafeeiras na região sul de Minas Gerais. Coffee Science, Lavras, v. 10, n. 4, p. 475-481, out/dez. 2015.

SANTOS, A. V.; GOMES, C. B. Reação de cultivares da mamona a Meloidogyne spp. e efeito dos exsudatos radiculares sobre Meloidogyne enterolobii e $M$. graminicola. Nematologia Brasileira, Piracicaba, v. 35, n. 1-2, p. 1-9, jan/jun. 2011. 
SANTOS, A. V. et al. Reaction of Coffea canephora clones to the root knot nematode, Meloidogyne incognita. African Journal of Agricultural Research, Lagos, v. 12, n. 11, p. 916-922, Mar. 2017.

SASSER, J. N.; CARTER, C. C.; HARTMAN, K. $M$. Standardization of host suitability studies and reporting of resistance to root-knot nematodes. Raleigh, NC: NCSU Graphics, 1984, p. 1-5.

SEINHORST,J.W.Therelationships between population increase and population density in plant-parasitic nematodes. II. Sedentary nematodes. Nematologica, California, v. 13, n. 1, p. 157-171, 1967.

SILVA, R. V. et al. Respostas de genótipos de Coffea spp. a diferentes populações de Meloidogyne exigua. Fitopatologia Brasileira, Brasília, v. 32, n. 3, p. $205-$ 212, May/June. 2007.

SILVA, R. V. et al. Defense responses to Meloidogyne exigua in resistant coffee cultivar and non-host plant. Tropical Plant Pathology, Viçosa, v. 38, n. 2, p. 114121, Mar/Apr. 2013.
SILVA, R. V.; OLIVEIRA, R. D. L.; ZAMBOLIM, L. Primeiro relato de ocorrência de Meloidogyne paranaensis em cafeeiro no estado de Goiás. Nematologia Brasileira, Brasília, v. 33, n. 1, p. 187190, jan/mar. 2009.

VANSTONE, V. A.; HOLLAWAY, G. J.; STIRLING, G. R. Managing nematode pests in the southern and western regions of the Australian cereal industry: continuing progress in a challenging environment. Australasian Plant Pathology, South Perth, v. 37, n. 3, p. 220-234, May/June. 2008.

VIEIRA JÚNIOR, J. R. et al. Levantamento da ocorrência de populações do nematoide-das-galhas-docafeeiro (Meloidogyne sp.) em Rondônia - primeira atualização. Comunicado Técnico, v. 397, p. 1-5, 2015.

VILLAIN, L. et al. A high-throughput method for early secreening of coffee (Coffea spp.) genotypes for resistance to root-knot nematodes (Meloidogyne spp.). European Journal of Plant Pathology, Dordrecht, v. 128, n. 4, p. 451-458, Dec. 2010 